\title{
Human Smoking - Animal Passive Smoking: What Do We Learn from It about Inflammatory Bowel Disease?
}

\author{
Shimon Reif \\ Sourasky Medical Center, Pediatric Gastroenterology, Tel-Aviv, Israel
}

There have recently been marked advances in elucidating the genetic factors involved in inflammatory bowel disease (IBD) [1,2]. At the same time, epidemiological studies have clearly demonstrated a major effect on the part of environmental factors [3, 4]. It is now strongly believed that combinations of distinct genetic backgrounds and environmental elements comprise the main factors in the pathogenesis of IBD [5]. Among the various environmental factors, the most established one is the effect of smoking [6, 7]. Numerous studies, although not all, have clearly demonstrated a protective effect of smoking on ulcerative colitis (UC) and its deleterious effect on Crohn's disease (CD). Thus, current smokers are less likely to develop UC whereas previous smokers are at a higher risk of developing UC than non-smokers, especially during the first years following the cessation of smoking [8-11]. A protective effect of smoking was further demonstrated by the therapeutic effect of nicotine patches to ameliorate disease activity in UC patients [12].

There have been far fewer investigations into the effects of passive smoking on IBD. Sandler et al. [13] reported that passive smoking decreases the risk of UC, while Persson et al. [10] found an increased risk of CD only in individuals exposed to environmental tobacco smoke in childhood. Interestingly, Lashner et al. [14] found a positive association between the passive exposure to smoking around the time of birth in both $\mathrm{CD}(\mathrm{OR}$ 5.3) and UC (OR 2.1) patients. We have not found any ef- fect of smoking on IBD adult patients [15]. Nicotine was even tried as a therapeutic approach or as a preventive measurement in UC patients in remission to prevent relapse [16]. Most of the current data demonstrate an association between smoking and IBD based on epidemiologic evidence. Those studies, however, concentrated more on evaluating direct smoking, and so little information exists on the effect of passive smoking, which is more complicated to assess in an epidemiologic study design. Therefore, the data are highly conflicting, unlike those on the effect of direct smoking. In contrast, while it is quite difficult to study the effect of smoking on laboratory animals, it is far more feasible to technically study the effect of 'passive smoking' on them and this is what was checked in the study by Sun et al. [17]. They induced experimental colitis by a well-established model of administering trinitrobenzene sulfonic acid (TNBS) enemas to rats. Passive smoking was induced by exposing the rats to 2 or $4 \%$ cigarette smoke-filled air for $1 \mathrm{~h}$ during 8 consecutive days. The authors found that exposure to smoking improved the colonic inflammation, as assessed by the enhanced appearance of the colonic mucosa, by the histological inflammation score and by increased myeloperoxidase activity and tissue TNF $\alpha$ levels, which are well-recognized markers of colitis activity. Thus, the effect of smoking on colitis can be demonstrated at all levels, specifically, macroscopically, microscopically and molecularly, including the main inflammatory mediator,

\section{KARGER}

Fax +4161306 1234 E-Mail karger@karger.ch www.karger.com (c) 2007 S. Karger AG, Basel 0012-2823/07/0764-0179\$23.50/0

Accessible online at: www.karger.com/dig
Shimon Reif

Sourasky Medical Center, Pediatric Gastroenterology

6 Weizman Street, Tel-Aviv 64239 (Israel)

Tel./Fax +972 36974515

E-Mail reif_shimon@hotmail.com or shimon_reif@med.unc.edu 
TNF $\alpha$. Furthermore, they showed [17] that the effect of smoking may be mediated by colonic $\alpha 7$ nicotinic acetylcholine receptor, which was up-regulated by the presence of cigarette smoking.

The mechanism by which smoking affects IBD is unclear. Several studies have suggested nicotine as being the mediator [18]. Indeed, it was shown $[12,16]$ that nicotine may have a therapeutic effect in UC patients either by means of transdermal nicotine patches or by nicotine enemas. Their study also provides another line of evidence that nicotine has a deleterious effect in TNBS-induced colitis via colonic $\alpha 7$ nicotinic acetylcholine receptors. There are, however, some limitations to the study that need to be considered. The authors used four rat groups: normal non-exposed controls, rats with TNBS-induced colitis, and rats with colitis which were exposed to 2 and $4 \%$ cigarette smoke air. This experimental design lacks another crucial control group, that of non-ill rats exposed to passive smoking. Without that group, it is not possible to conclude anything about the effects of cigarette smoke on animals with colitis in comparison to normal animals. Another piece of data that this study fails to provide is the blood nicotine level of the animals that were exposed to cigarette smoke. The colitis in this study was induced by TNBS, which is an acceptable model of Crohn's colitis (Th1 type) [19]. In the current study by Sun et al. [17], a short duration of TNBS administration for 8 days was used, which is more compatible with acute colitis. In order to induce chronic colitis, up to 8 weeks of treatment would be superior. As expected, in $\alpha 5$ nicotinic acetylcholine receptor knockout mice, Orr Urtegar et al. [18] found in a UC model that they developed more severe experimental colitis than the wild-type mice. Finally, although the study very nicely shows that passive smoking increases inflammation in TNBS-induced colonic colitis, it cannot mimic the 'human model' in which passive smoking occurs during prolonged periods and not for as few as 8 days. In addition, smoking concentration in a realistic setting is not constant nor is it limited to $1 \mathrm{~h} /$ day. Moreover, many other environmental factors that can be synergistic or antagonistic play a role in human exposure and they do not exist in animal models. Those limitations notwithstanding, this study adds important information to the mysterious effect of smoking in IBD.

\section{References}

1 Van Limbergen J, Russell RK, Nimno ER, Satsangi J: The genetics of inflammatory bowel disease. Am J Gastroenterol 2007;102: 2820-2831.

2 Chamillrad M, Iacob R, Desreumaux P, Colombel JF: Advances and perspectives in the genetics of inflammatory bowel diseases. Clin Gastroenterol Hepatol 2006;4:143-151.

3 Lakatos PL: Recent trends in the epidemiology of inflammatory bowel diseases: up or down? World J Gastroenterol 2006;12:61026108 .

4 Halfvarfson J, Jess T, Magnuson A, Montgomery SM, Orholm M, Tysk C, Binder V, Jarnerot G: Environmental factors in inflammatory bowel disease: a co-twin control study of a Swedish-Danish twin population. Inflamm Bowel Dis 2006;12:925-933.

5 Tuvlin JA, Raza SS, Bracamonte S, Julian C, Hanauer SB, Nicolae DL, King AC, Cho JH: Smoking and inflammatory bowel disease: trends in familial and sporadic cohorts. Inflamm Bowel Dis 2007;13:573-579.

6 Karban A, Eliakim R: Effect of smoking on inflammatory bowel disease: Is it disease or organ specific? World J Gastroenterol 2007; 13:2150-2152.
7 Mahid SS, Minor KS, Soto RE, Horning CA, Galandiuk S: Smoking and inflammatory bowel disease: a meta-analysis. Mayo Clin Proc 2006;81:1462-1471.

8 Calkins B: Meta-analysis of smoking in inflammatory bowel disease. Dig Dis Sci 1989; 34:1841-1845.

9 Tobin MV, Logan RF, Langman MJ, McConnel RB, Gilmot IT: Cigarette smoking and IBD. Gastroenterology 1987;93:316-321.

10 Persson PG, Ahlbom A, Hellers G: Inflammatory bowel disease and tobacco smoke - a case-control study. Gut 1990;31:1377-1381.

11 Reif S, Klein I, Arber N, Gilat T: Lack of association between smoking and inflammatory bowel disease in Israel. Gastroenterolgy 1995;108:1683-1687.

12 Pullan RD, Rhodes J, Ganesh J, Mani V, Morris JS, Williams GT, Newcomb RG, Russel MAH, Feyerabend G, Thomas GAO, Saw U: Transdermal nicotine for active ulcerative colitis. N Engl J Med 1994;330:811-815.

13 Sandler RS, Sandler DP, McDonnell CW, Wurzelmann JL: Childhood exposure to environmental tobacco smoke and the risk of ulcerative colitis. Am J Epidemiol 1992;185: 603-608.

14 Lashner BA, Shaheen NJ, Hanauer SB, Kirschner BS: Passive smoking is associated with increased risk of developing inflammatory bowel disease in children. Am J Gastroenterol 1993;88:356-359.
15 Eliakim R, Reif S, Lavy A, Keter D, Odes S, Halak A, Broide E, Niv Y, Ron I, Paz J, Fich A, Villa Y, Gilat T: Passive smoking in patients with inflammatory bowel disease: an Israeli multicentre case-control study. Eur J Gastroenterol Hepatol 2000;12:975-979.

16 Sandborn WJ, Tremine WJ, Offord KP, Lawson GM, Peterson BT, Batts KP, Croghan IT, Dale LC, Schroeder DR, Hurt DR: Transdermal nicotine for mildly to moderately active ulcerative colitis. A randomized, doubleblind, placebo-controlled trial. Ann Intern Med 1997;126:364-371.

17 Sun YP, Wang HH, He Q, Cho CH: Effect of passive cigarette smoking on colonic $\alpha 7$-nicotinic acetylcholine receptors in TNBS-induced colitis in rats. Digestion 2007;76:181187.

18 Orr Urtegar A, Kedmi M, Rosner S, Karmeli F, Rachmilewitz D: Increased severity of experimental colitis in $\alpha 5$ nicotinic acetylcholine receptor subunit-deficient mice. Neuroreport 2005;16:1123-1127.

19 Wirtz S, Eufert C, Weigman B, Neurath M: Chemically induced mouse models of intestinal inflammation. Nat Protoc 2007;2:541546 . 